\title{
Solving Short-Termism
}

TO PROMOTE A LONG-TERM FOCUS, CHANGE THE COMPANY OWNERSHIP MODEL

By Laurie Fitzjohn-Sykes, CFA

There is increasing evidence and acknowledgement that the West has a problem with short-termism in business. However, not enough is being done to solve this problem. As I argue in my recently published book, Playing the Long Game, by looking at the lessons of history, we can see the choices we can no longer afford to ignore. Most importantly, we face a choice between reverting to a more closed system of company ownership and control or embracing a new, transparent system of collective research and engagement.

First, look at the evidence. Investment in fixed assets in many Western countries is low and still declining. More worrisome, the Western level of R\&D investment is also falling behind that of the East. The fall in investment has been mirrored by increasing cash returned to shareholders via dividends and buybacks. Further, in the UK and the US, companies have now become net savers in the economy. Companies came into existence to act as conduits for investment, to take money from individuals and the government to carry out investment. But this function has now reversed; companies in aggregate are net savers in our economy, lending money to consumers and the government to buy the goods and services the companies provide.

This development should not come as a surprise given the number of shortterm biases in the ownership and governance structures for listed companies. For example, stock holding periods have been falling for decades. CEO tenure is diminishing. Executive pay is generally based on a three-year horizon-considerably less than the average company's investment cycle. Fund managers' performance is often assessed monthly, with yearly bonuses. Research providers are predominantly paid by hedge funds rather than by long-only funds.

As a result of these biases, increasing numbers of companies are choosing to stay private, and the number of listed companies is decreasing. The most innovative companies are often private or founder controlled. There is an increasingly compelling case that the US and UK model of corporate control is broken. The system of fragmented ownership combined with a shareholder value focus does not appear to be working. Investment is declining, and entrepreneurs are shunning this model for company ownership. As is often the case when facing a big question, the answer may come from looking into history.

Many people say that short-termism is an unavoidable part of our capitalist system. But if history teaches us anything, it is that the purpose of companies has been constantly changing. Companies are now so ubiquitous that we often forget their contentious beginning in the mid-19th century, when many prominent figures argued against limited liability and the creation of a legal entity separate from the individual.

Initially, companies were controlled by founding families who had large ownership stakes. Then, in the 1920s and 1930s in the US and the UK, these founding families started to sell their stakes. The ownership of our largest companies became increasingly fragmented. As a result, in the 1950s and 1960s, the control of companies increasingly fell to the board of directors in what is called "managerial capitalism." This trend is captured by a 1953 article in the Economist that said, "[Shareholders] rank well after the employees, the progress of 'the company', and the wellbeing of the customer in the thoughts of the directors whom-in legal form-they appoint" ["The Shareholder Today," 19 December 1953, 903-4]. This model of corporate control led to accusations of corporate excess and managers running companies for their own personal benefit.

The situation changed again in the 1980s as buyout funds, cheap debt financing, and a change in political approach led to a takeover boom. Companies were acquired and refocused onto core operations and creating shareholder value. In response to the risk of takeovers, management and boards sought to align themselves with shareholders by issuing themselves stock options. The shift in corporate purpose to what is now called the "shareholder value focus" was dramatic.

The problem is that a focus on shareholder value has resulted in a focus on short-term profit. Investment funds hold stakes too small in companies to make long-term engagement an option and instead seek to deliver returns through active trading. This trading has become overly focused on quarterly profit, leading companies to have a shorter-term focus.

Alongside the change in company ownership and control came an equally significant change in how individuals invested in company shares. Individuals initially held shares directly in companies. Then in the 1920 s and 1930s, as the controlling families sold out, the industry of professional fund management started to develop. This trend was encouraged by advantageous tax breaks for mutual funds and pensions. Steadily, the proportion of company shares held by professional fund managers grew, and it is now above $75 \%$ in the US and the UK.

The success of the fund management industry is now becoming self-defeating. When the industry was small, many fund managers could plausibly hope to outperform the market, as the majority of the market was made up of amateur investors. Individuals were happy to pay an annual management fee for this expected outperformance. However, now that professional fund managers account for the majority of the market, they cannot all outperform the market, for they have become the market. As a result, investors are increasingly less willing to pay high annual management fees for underperformance. This shift is leading to growth in low-cost passive investment funds and pension funds that bring active management in-house. Thus, many long-only active managers are struggling. 
In short, over the past hundred years, slow changes in ownership built up over time to dramatically change the purpose and control of companies.

Furthermore, the current system for company ownership and control has created two critical problems. First, funds are charging $1 \%$ management fees on the promise of outperformance that, in aggregate, they cannot deliver. Second, funds own such small stakes in companies that they focus on trading shares rather than engaging with management to deliver long-term value.

We have a system that is both costly to savers with annual management fees and not supportive of companies in creating long-term value. As a result, we are at a crossroad for both company ownership and the fund management industry.

We could revert to a more closed system of company ownership and control, shifting back toward the larger ownership stakes in companies that we see in Asia or that existed in the
US and the UK prior to the 1920s. Or we could provide more power to the board of directors, as was similarly done in the days of managerial capitalism. Both of these changes result in providing one part of the system with the power and influence to take a longerterm view. The downside is that they create a more closed system, placing investors' trust in either large shareholders or the board to make the right decisions for the long term.

Alternatively, we could create a new system based on transparency, with collective research and engagement. Currently, it is unrealistic to expect each fund to carry out extensive research

\section{KEEP GOING}

For more on reforming sell-side research, see the author's Viewpoint article "The Cinderella of Finance?" in the March/April 2015 issue of CFA Institute Magazine. and engagement from a $1 \%$ management fee charged on a small company ownership stake. Instead, there could be much more collective research, which could be achieved by reforming sell-side research to provide in-depth, long-term focused research rather than the current plethora of short-term trading calls (for example, spinning out research from investment banking and enabling consolidation to create large independent research houses). Similarly, on engagement, regulators should encourage funds to group together to collectively engage with companies, both to spread around the cost of engagement and to increase the influence over management. The current short-term focus is anything but unavoidable.

Laurie Fitzjohn-Sykes, CFA, is the director of research at the not-for-profit think tank Tomorrow's Company in London. He is author of Playing the Long Game: How to Save the West from Short-Termism. Previously, he worked in sellside research and venture capital.

\section{LETTERS}

\section{ANOTHER PERSPECTIVE ON FINANCING COLLEGE}

Despite the disclaimer in Ralph Wanger's recent column about equity financing of college educations (Chapter 10, "The Student Fund, LP," September/October 2015), I did not find the piece ironic or sarcastic. I saw it as a very well-thought-out and structured proposal to address a prominent issue facing our economy. I believe the proposal should be debated on its merits-hopefully by our society at large, but at the very minimum, within our rarefied world of financial services.

At first glance, equity financing for college education seems to be an excellent alternative to debt financing. It's not hard to imagine a well-functioning market where both parties (investors and students) benefit.

However, as I thought a little more, I had some doubts. Such a market would rely on reasonable models that can predict which students are good investments. In fact, I expect such predictive models to (eventually) do an excellent job. My guess is that such models would in general predict that students with good grades and high test scores who come from affluent families would be safer investments. The riskier pools of students would likely have a higher proportion of less affluent students, quite possibly with a much higher proportion of minority students.

The riskiest pools could then theoretically be handled in one of four ways:

1. Students in this pool do not get a college education.

2. Investment terms are fairly harsh to compensate for the risk (say, $50 \%$ of annual income above $\$ 40,000$ ).

3. The government steps in either as an insurer or an investor (think Freddie Mac and Fannie Mae).

4. Regulations require investable portfolios to have a mix of students from all risk pools.

Options 1 and 2 don't work if you believe that society should offer such students a fair shot at college education-and even if you don't believe that, you must acknowledge that any proposal that leaves out such students is a political nonstarter. Additionally, even with the best predictive models, it's reasonable to expect that the riskier pools will have at least some students who would turn out to be excellent future contributors to the society, even in purely economic terms. Such students could pay a particularly exorbitant price for having markers that classify them as "risky investments."

In that case, all that the equity financing would achieve is to split the students into pools and to leave the credit risk largely to taxpayers (Options 3 and 4).

To me, it comes down to one question. What's likely to work better: a stick (you need to work hard to pay back your loans) or a carrot (you should work hard so you can pay back your investors someday and get additional money to spend)?

Tarun Garg, CFA, is an investment professional based in New Jersey. 